\title{
The Impact of Faculty of Study on Students' Satisfaction: A Study of Four Private Universities in Nigeria
}

\author{
Oluwunmi Adedamola Olufunke ${ }^{1}$ \\ ${ }^{1}$ Department of Estate Management, Covenant University, Ota, Ogun State, Nigeria \\ Correspondence: Oluwunmi Adedamola Olufunke, Department of Estate Management, Covenant University, Ota, \\ Ogun State, Nigeria. E-mail: funke.oluwunmi@covenantuniversity.edu.ng
}

Received: October 9, 2014 Accepted: February 5, 2015 Online Published: June 28, 2015

doi:10.5539/ies.v8n7p57

URL: http://dx.doi.org/10.5539/ies.v8n7p57

\begin{abstract}
Due to the increasing number of educational institutions in Nigeria, Universities (particularly private Universities) are competing to attract more students into their faculties. In a bid to achieve this goal, these Universities are making all efforts to satisfy their students. This paper therefore examines the impact of the faculty of study on students' satisfaction with academic facilities in four (4) private Universities in Ogun State, Nigeria. To achieve this, seven hundred and seventy (770) questionnaires were developed and distributed randomly to the students and a response rate of $71 \%$ was achieved. Data was analysed using frequency tables, percentages, cross-tabulation and Kruskal Wallis Test. The result of the analysis reveals that faculty of study significantly influences students' satisfaction. Implications of these finding and future research directions are discussed.
\end{abstract}

Keywords: students, satisfaction, academic facilities, private universities, programme, Nigeria

\section{Introduction}

Private institutions of higher learning are constantly competing with public institutions for student enrolment. This is expected, as failure to maintain adequate levels of enrolment can be a significant challenge to the financial viability of the institutions. According to a report by the U.S. Department of Education, 114 private non-profit degree-granting colleges have failed to meet the Department's financial-responsibility test, a potential indicator of survivability. All over the world, institutions of higher learning (both public and private) that cannot attract sufficient numbers of students are vulnerable to closure or must seek mergers with financially healthier ones. Therefore, to remain financially viable, colleges must be able to meet a minimum level of enrolment of students (Porter, 1980; Bolda \& Bruce, 1983; Blumenstyk, 2009; Long \& Adukia, 2009; Brunson, 2010).

Students' satisfaction has been identified to have a significant impact on maintaining students' loyalty and retention (Cronin \& Taylor, 1992; Voon, 2006; Brunson, 2010). For instance, Voon's (2006) study found that perceived service quality in higher education had a greater impact on customer satisfaction and loyalty than maintaining a service market orientation by the higher educational institution. However, majority of the studies both in Nigeria and developed countries have focused on the relationship between students' satisfaction and demographic factors such as age, sex, marital status, year of study and nationality (Soutar \& McNeil, 1996; Umbach \& Porter, 2002; Perry, Sekelsy, \& Skarsten, 2003; Tessema, Ready, \& Malone, 2012).

The studies of Soutar and McNeil (1996), Umbach and Porter (2002) and Perry, Sekelsy and Skarsten (2003) on relationship between sex and students' satisfaction with service quality in tertiary institutions reveal that there is a significant relationship between gender and satisfaction with service quality as males are more satisfied than females. A similar study in the UK by Oldfield and Baron (2000) evaluated students' perception of service quality over time and revealed that the mean score for the final year students was lower than those of the first year students. This finding implies that as students become more experienced in higher educational settings, they tend to be more critical in their perceptions of the service quality. Also, Yusoff (2011) identified and evaluated the drivers that influence business students' satisfaction in Malaysia's private educational environment. One thousand two hundred $(1,200)$ questionnaires were distributed to undergraduate business students at four private educational institutions in Malaysia. A total of 823 responses were found to be usable for analysis, giving a response rate of $69 \%$. The result revealed that significant differences exist between the demographic factors and five factors (student support facilities, class sizes, classroom environment, business procedures and relationship 
with the teaching staff). In the US, Tessema, Ready, and Malone (2012) carried out a research on the effect of gender on different college outcomes such as students' satisfaction, ACT scores, and grade point average (GPA) at a mid-sized Midwestern public University. The authors distributed questionnaires to a sample of 5,223 senior students representing five colleges (Business, Education, Liberal Arts, Nursing/Health Sciences and Science/Engineering) in the University. Findings showed that gender has a significant effect on student's satisfaction, ACT scores and GPA. However, the effect of gender on satisfaction and ACT scores was minimal. However, other studies reported otherwise. Carey, Cambiano, and De Vore (2002) in the US compared campus satisfaction levels between students and faculty as measured by the Student Satisfaction Inventory (SSI) and the Institutional Priorities Survey (IPS). The student sample consisted of 692 (397 females and 295 males) from a Midwestern state University. Both student and faculty respondents rated all items on a 7-point Likert scale on their expectation and satisfaction with student services. Results of the t-test indicated that there was no significant difference between male and female $(\mathrm{t}=.49 ; \mathrm{t}=.62)$ responses, age and ethnicity. Ham and Hayduk (2003) also asserted that gender has no significant relationship with perceived service quality even though males seem to be more satisfied than females.

In summary, the foregoing review shows that several studies have looked into the relationship between students' characteristics and satisfaction. However, in Nigeria and other developing countries, there is a need for further studies on the relationship between students' faculty of study and satisfaction. Of particular reference to this study is the work of Corts, Lounsbury, Saudargas, and Tatum (2000) which assessed undergraduate satisfaction at the Psychology Department of the University of Tennessee, Knoxville, US. Out of 289 students that completed the questionnaire, $209(71 \%)$ were women and $80(27 \%)$ were men. The analysis with one-way ANOVAS and a t-test revealed no significant differences between students' satisfaction with their academic department based on year in school, sex, and cumulative Grade Point Average (GPA). A similar study in Nigeria by Olasehinde-Williams (2006) compared the degree of satisfaction of full-time and part-time students to programme facilities at the University of Ilorin. Ninety-six (96) students randomly selected from full-time and part-time studies at the University during the Harmattan semester of the 2000/2001 academic session participated in the study. Using the "Student Behavioural Rating Scale" designed by Kolawole et al. (1995), data was collected in respect of the students' perception of five major aspects of their degree programmes (i.e. the course studied; programme facilities; lecturers; colleagues and the profession). Focusing on programme facilities, being one of the constituents of the degree programme, the extent to which the students differ in their perceptions were determined using t-statistics and the variables of type of programme (full-time and part-time). Findings revealed that there are slight variations in the students' expression of their satisfaction with different aspects of their programme facilities. Therefore, the author suggested the need for periodic investigation of students' perceptions of the quality of their programme facilities to ensure maximum actualisation of the students' academic and behavioural potentials and programme objectives. Although, these studies serve as a basis for this present one, the current paper however differs in the methodology adopted. It is on this note that this study is set to investigate the impact that faculty of study has on students' satisfaction with academic facilities in Private Universities in Ogun State, Nigeria.

\section{Research Method}

In order to achieve the objective of the study, the research sampled 770 students of four (4) private Universities in Ogun State, Nigeria. A total of 546 questionnaires (representing 71\%) were retrieved for analysis. Table 1 shows the response rates per University. Data was analysed using frequency tables, percentages, Cross-tabulation and Kruskal Wallis Test.

Table 1. Response rate

\begin{tabular}{llccc}
\hline S/N & University & \multicolumn{2}{c}{ No. of Questionnaires } & Percentage (\%) Retrieved \\
\cline { 1 - 3 } & & Administered & Retrieved & \\
\cline { 1 - 3 } 2 & Babcock University (BU) & 198 & 136 & 69 \\
3 & Covenant University (CU) & 199 & 162 & 81 \\
4 & Redeemer's University (RUN) & 187 & 140 & 75 \\
4 & Crescent University (CRE) & 186 & 108 & 58 \\
& Total & 770 & 546 & 71 \\
\hline
\end{tabular}




\subsection{Classification of the Faculties}

For uniformity, the students' faculties of study have been classified into three (3) groups. The first group comprises students in Science and Technology (Engineering, Environmental, Sciences, Medicine, Pharmacy, Mathematics, Computer, Agriculture and Technology), the second group comprises students in Social Sciences (Management, Business, Marketing, Economics, Accounting, Banking and Finance Political Science, Sociology, International Relation and Public Admin and Mass Communication) while the third group consists of students in Humanities (Law, Education, English, philosophy, psychology, Religious Studies, History, Theatre Art/Fine Art and French). Table 2 shows the details of the academic programme classification.

Table 2. Faculty/academic programme classification

\begin{tabular}{|c|c|c|c|c|c|}
\hline $\mathrm{S} / \mathrm{N}$ & $\begin{array}{l}\text { Faculty/Academic } \\
\text { Programme } \\
\text { Classification }\end{array}$ & Babcock University & Covenant University & $\begin{array}{l}\text { Redeemer's } \\
\text { University }\end{array}$ & Crescent University \\
\hline \multirow{3}{*}{1} & \multirow{3}{*}{ Science and Technology } & $\begin{array}{l}\text { School of Science } \\
\& \text { Technology }\end{array}$ & $\begin{array}{c}\text { School of } \\
\text { Engineering and } \\
\text { Technology }\end{array}$ & $\begin{array}{c}\text { College of } \\
\text { Natural Sciences }\end{array}$ & $\begin{array}{c}\text { College of Natural and } \\
\text { Applied Sciences (CONAS) }\end{array}$ \\
\hline & & & $\begin{array}{c}\text { School of } \\
\text { Environmental } \\
\text { Sciences }\end{array}$ & & $\begin{array}{l}\text { College of Environmental } \\
\text { Sciences (COES) }\end{array}$ \\
\hline & & & $\begin{array}{c}\text { School of Natural } \\
\text { and Applied Sciences }\end{array}$ & & $\begin{array}{l}\text { College of Information and } \\
\text { Communication Technology } \\
\text { (CICOT) }\end{array}$ \\
\hline \multirow[t]{2}{*}{2} & \multirow[t]{2}{*}{ Social Science } & $\begin{array}{c}\text { School of } \\
\text { Management \& } \\
\text { Social Sciences }\end{array}$ & $\begin{array}{l}\text { School of Social } \\
\text { Science }\end{array}$ & $\begin{array}{l}\text { College of } \\
\text { Management } \\
\text { Sciences }\end{array}$ & $\begin{array}{l}\text { College of Social and } \\
\text { Management Science } \\
\text { (COSMAS) }\end{array}$ \\
\hline & & & School of Business & & \\
\hline \multirow[t]{2}{*}{3} & \multirow[t]{2}{*}{ Humanities } & $\begin{array}{l}\text { School of Education } \\
\text { \& Humanities }\end{array}$ & $\begin{array}{l}\text { School of Human } \\
\text { Resources } \\
\text { Development }\end{array}$ & $\begin{array}{l}\text { College of } \\
\text { Humanities }\end{array}$ & College of Law (COLAW) \\
\hline & & $\begin{array}{l}\text { School of Law and } \\
\text { Security Sciences }\end{array}$ & & & \\
\hline
\end{tabular}

\section{Results}

\subsection{Students' Faculty of Study in the Selected Private Universities}

The analysis for the programme of students in the four private Universities is shown in Table 3. The survey shows that the respondents in Babcock University were evenly spread across the faculties while there are more respondents (50\% and 57\% respectively) from Science and Technology in Covenant University and Crescent University as against $61 \%$ from Social Science in Redeemer's University. On the average, $41 \%, 35 \%$ and $24 \%$ of the respondents are from Science and Technology, Social Science and Humanities respectively across the four Universities. It can therefore be deduced from this analysis that majority of the respondents are science students.

Table 3. Students' faculty of study in selected private universities

\begin{tabular}{lcccccc}
\hline College/Statistics & Sub-headings & BU & CU & RUN & CRE & Mean \% \\
\hline \multirow{2}{*}{ Academic Programme Classification } & F (\%) & F (\%) & F (\%) & F (\%) & \\
& Science \& Technology & $44(32)$ & $81(50)$ & $37(26)$ & $62(57)$ & 41 \\
& Social Science & $44(32)$ & $32(20)$ & $85(61)$ & $28(26)$ & 35 \\
& Humanities & $48(36)$ & $49(30)$ & $18(13)$ & $18(17)$ & 24 \\
\hline
\end{tabular}

Note. The Figures in brackets are percentages of responses. 


\subsection{Impact of Faculty of Study on Students' Satisfaction}

Using Kruskal Wallis Test, the result in Table 4 shows that there is a significant difference between students in the different faculties of the four Universities $\{$ (Babcock University $(\mathrm{H}(2)=36.520, \mathrm{P}=.000<0.05)$, Covenant University $(\mathrm{H}(2)=16.432, \mathrm{P}=.000<0.05)$, Redeemer's University $(\mathrm{H}(2)=13.790, \mathrm{P}=.001<0.05)$ and Crescent University $(\mathrm{H}(2)=16.984, \mathrm{P}=.000<0.05)\}$. Hence, students' faculty of study significantly affects students' level of satisfaction. To further ascertain the students of the faculties that are particularly satisfied with the academic facilities in each of the Universities, the research adopted cross-tabulation as shown in Tables 5 to 8 . The analysis indicates that students in Science and Technology in Covenant University and Crescent University are more satisfied than students from other faculties. However, in Babcock University and Redeemer's University, students in Humanities and Social Science respectively have a greater chance of being satisfied than other students.

Table 4. Comparison of means satisfaction of students based on faculty of study (Kruskal Wallis test)

\begin{tabular}{llcccc}
\hline University & Group & $\mathrm{N}$ & Mean Rank & Chi-Square & $\mathrm{P}$ \\
\hline BU & Science \& Technology & 44 & 52.72 & 36.520 & .000 \\
& Social Sciences & 44 & 57.32 & & \\
& Humanities & 48 & 93.22 & & \\
CU & Science \& Technology & 81 & 68.54 & 16.432 & .000 \\
& Social Sciences & 32 & 85.75 & & \\
& Humanities & 49 & 100.14 & & \\
RUN & Science \& Technology & 37 & 62.84 & 13.790 & .001 \\
& Social Sciences & 85 & 67.08 & & \\
& humanities & 18 & 102.39 & & \\
CRE & Sciences \& Technology & 62 & 48.55 & 16.984 & .000 \\
& Social Sciences & 28 & 50.29 & & \\
& Humanities & 18 & 81.56 & & \\
\end{tabular}

The difference is significant if $P<0.05$.

The difference is insignificant if $P>0.05$.

Table 5. Relationship between students' faculty of study and overall satisfaction (Babcock University)

\begin{tabular}{|c|c|c|c|c|c|c|}
\hline & & \multicolumn{4}{|c|}{ Faculty } & \multirow[t]{2}{*}{ Total } \\
\hline & & & Science and Technology & Social Science & $\overline{\text { Humanities }}$ & \\
\hline \multirow{10}{*}{ Overall Satisfaction } & Strongly dissatisfied & Count & 0 & 0 & 0 & 0 \\
\hline & & $\%$ within faculty & 0 & 0 & 0 & 0 \\
\hline & Dissatisfied & Count & 0 & 0 & 0 & 0 \\
\hline & & $\%$ within faculty & 0 & 0 & 0 & 0 \\
\hline & Fair & Count & 14 & 11 & 0 & 25 \\
\hline & & $\%$ within faculty & 31.8 & 25 & 0 & 18.4 \\
\hline & Satisfied & Count & 15 & 16 & 5 & 36 \\
\hline & & $\%$ within faculty & 34.1 & 36.4 & 10.4 & 26.5 \\
\hline & Strongly Satisfied & Count & 15 & 17 & 43 & 75 \\
\hline & & $\%$ within college & 34.1 & 38.6 & 89.6 & 55.1 \\
\hline \multirow[t]{2}{*}{ Total } & & Count & 44 & 44 & $* 48$ & 136 \\
\hline & & $\%$ within faculty & 100 & 100 & 100 & 100 \\
\hline
\end{tabular}


Table 6. Relationship between students' faculty of study and overall satisfaction (Covenant University)

\begin{tabular}{|c|c|c|c|c|c|c|}
\hline & & \multicolumn{4}{|c|}{ Faculty } & \multirow[t]{2}{*}{ Total } \\
\hline & & & Science and Technology & Social Science & Humanities & \\
\hline & Strongly dissatisfied & Count & 0 & 0 & 0 & 0 \\
\hline \multicolumn{7}{|c|}{ Overall Satisfaction } \\
\hline & & $\%$ within faculty & 0 & 0 & 0 & 0 \\
\hline & Dissatisfied & Count & 2 & 0 & 0 & 2 \\
\hline & & $\%$ within faculty & 2.5 & 0 & 0 & 1.2 \\
\hline & Fair & Count & 26 & 4 & 0 & 30 \\
\hline & & $\%$ within faculty & 32.1 & 12.5 & 0 & 18.5 \\
\hline & Satisfied & Count & 26 & 14 & 21 & 61 \\
\hline & & $\%$ within faculty & 32.1 & 43.8 & 42.9 & 37.7 \\
\hline & Strongly Satisfied & Count & 27 & 14 & 28 & 69 \\
\hline & & $\%$ within faculty & 33.3 & 43.8 & 57.1 & 42.6 \\
\hline \multirow[t]{2}{*}{ Total } & & Count & $* 81$ & 32 & 49 & 162 \\
\hline & & $\%$ within faculty & 100 & 100 & 100 & 100 \\
\hline
\end{tabular}

Table 7. Relationship between students' faculty of study and overall satisfaction (Redeemer's University)

\begin{tabular}{|c|c|c|c|c|c|c|}
\hline & & \multicolumn{4}{|c|}{ Faculty of Study } & \multirow[t]{2}{*}{ Total } \\
\hline & & & Science and Technology & Social Science & Humanities & \\
\hline \multirow{10}{*}{ Overall Satisfaction } & Strongly dissatisfied & Count & 7 & 19 & 0 & 26 \\
\hline & & $\%$ within faculty & 18.9 & 22.4 & 0 & 18.6 \\
\hline & Dissatisfied & Count & 7 & 11 & 0 & 18 \\
\hline & & $\%$ within faculty & 18.9 & 12.9 & 0 & 12.9 \\
\hline & Fair & Count & 7 & 12 & 0 & 19 \\
\hline & & $\%$ within faculty & 18.9 & 14.1 & 0 & 13.6 \\
\hline & Satisfied & Count & 8 & 19 & 8 & 35 \\
\hline & & $\%$ within faculty & 21.6 & 22.4 & 44.4 & 25.0 \\
\hline & Strongly Satisfied & Count & 8 & 24 & 10 & 42 \\
\hline & & $\%$ within faculty & 21.6 & 28.2 & 55.6 & 30.0 \\
\hline \multirow[t]{2}{*}{ Total } & & Count & 37 & $* 85$ & 18 & 140 \\
\hline & & $\%$ within faculty & 100 & 100 & 100 & 100 \\
\hline
\end{tabular}


Table 8. Relationship between students' faculty of study and overall satisfaction (Crescent University)

\begin{tabular}{|c|c|c|c|c|c|c|}
\hline & & \multicolumn{4}{|c|}{ Faculty } & \multirow[t]{2}{*}{ Total } \\
\hline & & & Science and Technology & Social Science & Humanities & \\
\hline \multirow[t]{10}{*}{ Overall Satisfaction } & Strongly dissatisfied & Count & 12 & 5 & 0 & 17 \\
\hline & & $\%$ within faculty & 19.4 & 17.9 & 0 & 15.7 \\
\hline & Dissatisfied & Count & 12 & 4 & 0 & 16 \\
\hline & & $\%$ within faculty & 19.4 & 14.3 & 0 & 14.8 \\
\hline & Fair & Count & 12 & 7 & 0 & 19 \\
\hline & & $\%$ within faculty & 19.4 & 25.0 & 0 & 17.6 \\
\hline & Satisfied & Count & 13 & 6 & 8 & 27 \\
\hline & & $\%$ within faculty & 21.0 & 21.4 & 44.4 & 25.0 \\
\hline & Strongly Satisfied & Count & 13 & 6 & 10 & 29 \\
\hline & & $\%$ within faculty & 21.0 & 21.4 & 55.6 & 26.9 \\
\hline \multirow[t]{2}{*}{ Total } & & Count & $* 62$ & 28 & 18 & 108 \\
\hline & & $\%$ within faculty & 100 & 100 & 100 & 100 \\
\hline
\end{tabular}

\subsection{Discussion}

This study has been able to establish that students' faculty of study has significant impact on their satisfaction. Students in the different academic programme classifications in the selected private Universities have reported differing levels of satisfaction. In Covenant University and Crescent University, students in Science and Technology are more satisfied with their academic facilities than students in Social Science and Humanities whereas in Babcock University, students in Humanities are more satisfied than those in Science and Technology and Social Science. However, in Redeemer's University, Social Science students are more satisfied than students in other colleges. This means that students' faculty has significant effect on their level of satisfaction; this phenomenon should not be overlooked. It therefore implies that it must be taken into consideration while making plans for students' loyalty and retention in order to meet the minimum level of enrolment of students.

\section{Conclusions and Recommendations}

Based on the findings of the study, it is advised that the management of the Universities should consider enrolling more students in those faculties where students are already satisfied with the available academic facilities. Furthermore, provision should also be made to upgrade the academic facilities in Social Science and Humanities of Covenant University and Crescent University as well as Science and Technology and Social Science of Babcock University and Humanities and Science and Technology of Redeemer's University. These should be done with a view of satisfying the students which will in turn increase patronage of the Universities in this competitive academic environment.

\section{References}

Blumenstyk, G. (2009). More than 100 colleges fail Education Department's test of financial strength. The Chronicle of Higher Education, 55(39), A21.

Bolda, P. J. M., \& Bruce, A. (1983). A measurement of financial viability among private colleges. Montreal, Canada: Educational Research Association.

Brunson, K. W. (2010). Examining Relationships between Quality Perceptions, Satisfaction, and Student Brand Loyalty in a Higher Educational Organization (Unpublished Dissertation). Northcentral University, Prescott Valley, Arizona.

Carey, K., Cambiano, R. L., \& De Vore, J. B. (2002). Student to Faculty Satisfaction at a Mid-western University in the United States, HERDSA (pp. 93-97).

Corts, D. P., Lounsbury, J. W., Saudargas, R. A., \& Tatum, H. E. (2000). Assessing Undergraduate Satisfaction with an Academic Department: A Method and Case Study. College Student Journal, 34(3), 399-410.

Cronin, J., \& Taylor, S. A. (1992). Measuring service quality: A reexamination and extension. Journal of 
Marketing, 56(3), 55-68. http://dx.doi.org/10.2307/1252296

Ham, L., \& Hayduk, S. (2003). Gaining competitive advantages in higher education: Analyzing the gap between expectations and perceptions of service quality. International Journal of Value-Based Management, 16(3), 223-242. http://dx.doi.org/10.1023/A:1025882025665

Kowole, D. O., Bojuwoye, O., Awoyemi, M. O., \& Olasehinde, F. (1995). The Academic and Behavioural Ratings of Sandwich and Regular Education Students in Nigerian University of llorin. Retrieved from http://www.unilorin.edu.ng/journals/education/ije/june2003/Students\%27\%20Perceptions\%20of\%20Full-Ti me\%20and\%20Part-Time\%20Education\%20Programmes\%20in\%20the\%20University\%20Of\%20llorin.pdf

Long, B. T., \& Adukia, A. (2009). The Impact of the Financial Crisis on Tertiary Education World Wide: A Pilot Study. Retrieved from http://isites.harvard.edu/fs/docs/icb.topic1233409.files/Long\%20Adukia\%202009\% 20Impact $\% 20$ of $\% 20$ financial $\% 20$ crisis $\% 20$ on $\% 20$ tertiary\%20education.pdf

Olasehinde-Williams, O. (2006). Students' Perceptions of Full-time and Part-time Education Programmes in Nigerian University. Journal of Sociology and Education in Africa, 4, 97-110.

Oldfield, B. M., \& Baron, S. (2000). Student Perceptions of Service Quality in a UK University Business and Management Faculty. Quality Assurance in Education, 8(2), 85-95. http://dx.doi.org/10.1108/09684880010325600

Perry, M. J., Sekelsy, M. J., \& Skarsten, F. (2003). University of Michigan-Flint Student Satisfaction Surveys Results. Retrieved from http://www.vca.umlint.edu/

Porter, M. E. (1980). Competitive strategy: Techniques for analyzing industries and competitors. New York: Free Press.

Soutar, G., \& McNeil, M. (1996). Measuring service quality in a tertiary institution. Journal of Educational Administration, 34(1), 72-82. http://dx.doi.org/10.1108/09578239610107174

Tessema, M., Ready, K., \& Malone, C. (2012). Effect of Gender on College Students' Satisfaction and Achievement: The Case of a Midsized Midwestern Public University. International Journal of Business and Social Science, 3(10), 1-11.

Umbach, P. D., \& Porter, S. R. (2002). How do Academic Departments Impact Student Satisfaction? Understanding the Contextual Effects of Departments. Research in Higher Education, 43(2), 209-234. http://dx.doi.org/10.1023/A:1014471708162

Voon, B. H. (2006). Linking a service-driven market orientation to service quality. Managing Service Quality, 16(6), 595-616. http://dx.doi.org/10.1108/09604520610711927

Yusoff, M. (2011). Evaluating Business Student Satisfaction in the Malaysian Educational Environment (Unpublished professional phD thesis). University of Northumbria, Newcastle.

\section{Copyrights}

Copyright for this article is retained by the author(s), with first publication rights granted to the journal.

This is an open-access article distributed under the terms and conditions of the Creative Commons Attribution license (http://creativecommons.org/licenses/by/3.0/). 